\title{
Thermohaline properties in the Eastern Mediterranean in the last three decades: is the basin returning to the pre-EMT situation?
}

\author{
V. Cardin ${ }^{1}$, G. Civitarese ${ }^{1}$, D. Hainbucher ${ }^{2}$, M. Bensi ${ }^{1}$, and A. Rubino ${ }^{3}$ \\ ${ }^{1}$ OGS, Istituto Nazionale di Oceanografia e di Geofisica Sperimentale, Borgo Grotta Gigante 42/c, \\ 34018 Sgonico, Trieste, Italy \\ ${ }^{2}$ CEN, Institut für Meereskunde, University of Hamburg, Bundesstraße 53, 20146 Hamburg, Germany \\ ${ }^{3}$ Università Ca’ Foscari di Venezia, Dorsoduro 2137, 30121 Venice, Italy \\ Correspondence to: V. Cardin (vcardin@ogs.trieste.it)
}

Received: 27 December 2013 - Published in Ocean Sci. Discuss.: 3 February 2014

Revised: 3 November 2014 - Accepted: 14 December 2014 - Published: 9 January 2015

\begin{abstract}
Temperature, salinity and oxygen data collected during April and June 2011 (M84/3 and P414 cruises respectively) are analysed to derive the oceanographic characteristics of the Eastern Mediterranean (EM) basin. These observed characteristics are compared with those from previous cruises over the period 1987-2011. As a result, the interannual and decadal variability of the EM thermohaline properties are discussed in the context of the evolution of the Eastern Mediterranean Transient (EMT) and of the general circulation of the basin. We found that the state of the EM is still far from the pre-EMT conditions, though the 2011 results possibly indicate a slow return to this status. In particular, a comparison between thermohaline property evolution deriving from interannual variability of the preconditioning and air-sea interaction (heat fluxes) in the South Adriatic and the Cretan Seas reveals aspects of the alternation of the two dense water sources (Adriatic and Aegean) during the last three decades, which have strong implications for the hydrographic characteristics of the intermediate and deep layers of the Ionian and Levantine basins.
\end{abstract}

\section{Introduction}

The circulation of the Eastern Mediterranean (EM) is deeply influenced by several driving forces, strong topographic constraints and internal dynamic processes (Robinson et al., 1991). The basin-scale thermohaline circulation of the EM is formed by two cells: the closed internal cell of the deep circulation encompassing the Adriatic-Ionian area and the
Levantine basin, known as the EM conveyor belt, and the external thermohaline cell involving the exchange of water between the EM and the Western Mediterranean (Lascaratos et al., 1999). The first one, mainly driven by the formation of Adriatic Deep Water (AdDW), which eventually becomes the Eastern Mediterranean Deep Water (EMDW), is characterized by a renewal time of approximately 126 years (Roether and Schlitzer, 1991). Indeed, the major source of the deep waters of the EM can be considered the Adriatic Sea.

Recent decades have shown dramatic changes in the circulation of the EM. During the late 1980s and early 1990s, the EM conveyor belt underwent a major climate shift known as the Eastern Mediterranean Transient (EMT) (Roether et al., 1996, 2007; Theocharis et al., 2002), during which dense waters of Aegean origin replaced the AdDW in the deep layers of the EM. The structure of the South Aegean Sea (namely, the Cretan Sea; CS) water column changed as exceptionally dense and salty water started to fill the deep Cretan basin and to overflow the sills of the Cretan Arc straits. Observations conducted in 1987, 1991 and 1995 indicated a reduced transport of Atlantic Water (AW) into the Levantine basin, where the salinity increased, altering the circulation pattern of the Levantine Intermediate Water (LIW) from its formation site towards the Ionian Sea (Klein et al., 1999; Malanotte-Rizzoli et al., 1999). These drastic changes and the major contribution of dense water of Aegean origin continued for a period of 7-8 years. Due to its high density $\left(\sigma_{\theta}>29.35 \mathrm{~kg} \mathrm{~m}^{-3}\right)$, the Cretan Deep Water (CDW) continued to fill the deepest parts of the Levantine and Ionian basins, uplifting the resident and older deep and bottom waters of Adriatic ori- 
gin (Schlitzer et al., 1991; Roether et al., 1996; MalanotteRizzoli et al., 1997). CDW appeared to be the most important source of the new type of EMDW, the AdDW not being dense enough to spread over the bottom layer of the EM. The Aegean source apparently disappeared by about 1995 (Theocharis et al., 2002).

Hydrographic measurements obtained in 2003 indicate a new ventilation of the deep layers in the Adriatic and Ionian Seas (see Hainbucher et al., 2006; Manca et al., 2006; Cardin et al., 2011). The necessary preconditioning for deep convection in the Southern Adriatic (SA) and the formation of water dense enough to spread below the bottom water of EM origin were only re-established after 2005 , following a salinity increase linked with the influence of EM water at intermediate levels. However, bottom waters encountered in the deep layers of the Ionian basin were warmer and saltier between 2003 and 2007 (Rubino and Hainbucher, 2007). This implies the existence of a delayed link between characteristics of the intermediate layer of the SA and abyssal waters of the Ionian Sea (Bensi et al., 2013). Experimental observations show that the Northern Ionian Gyre (NIG) reverses on an almost decadal scale (Gačić et al., 2010). This reversal is driven by and responsible for internal mass redistribution within the EM. In particular, it seems mainly driven by variability in salinity (Gačić et al., 2011; Theocharis et al., 2014; Velaoras et al., 2014). Wind stress and other external forces play an important role as they interact with the abovementioned processes to shape the variability (strengthening or weakening) of the surface circulation regime and of the sub-basin ocean structures (Molcard et al., 2002; D’Ortenzio and Prieur, 2012; Pinardi et al., 2013). The result is a highly complex nonlinear system acting at very different spatial and temporal scales.

In the present study, we have analysed temperature, salinity and oxygen data collected during April and June 2011 (M84/3 and P414 cruises, respectively) to examine the oceanographic characteristics of the EM basin. We focused our attention particularly on the properties and possible pathways of the AdDW, the EMDW and the LIW. Their evolutions are put in the context of the evolution of the EM large-scale oceanographic properties and of the circulation during the last three decades. Finally, we discuss the interannual variability of the preconditioning (salt redistribution) and air-sea interaction (heat fluxes) in the two main densewater source areas for the EM, i.e. the South Adriatic and Cretan seas.

\section{Data and methods}

\subsection{M84/3 and P414 cruise data sets}

The hydrographic data analysed in this study were collected in the course of two German oceanographic cruises: $\mathrm{Me}$ teor M84/3 (April 2011) and Poseidon P414 (June 2011).
The Meteor M84/3 cruise was set up to follow the demands and requirements of repeating hydrography as specified by the GO-SHIP group (http://www.go-ship.org/), i.e. to obtain a comprehensive set of physical and chemical parameters measured to the highest standards. The aim of the cruise was to cover the quasi-zonal section through the Mediterranean Sea, covering the main basins of the Mediterranean Sea, with dense sampling of physical and chemical parameters throughout the whole water column. The primary goal of the Poseidon P414 (June 2011) cruise was to identify the routes of the AdDW into the Ionian Sea, so as to study the spatial and temporal variability of the spreading and mixing of the EMDW (Fig. 1a).

The data set has two main components: the continuous profiles of conductivity, temperature and depth (CTD), and the discrete data from the water samples. It contains information from 61 hydrographic stations sampled during the April cruise (M84/3) (more information in Tanhua et al., 2013) and 33 full-depth standard hydrographic stations sampled in June 2011 during the P414 cruise. A SeaBird SBE911plus $\mathrm{CTD}-\mathrm{O}_{2}$ probe equipped with dual sensors of temperature, salinity and dissolved oxygen was employed, attached to a SeaBird carousel water sampler (24-bottle during the M84/3 and 12-bottle during the P414), together with an altimeter. Additionally, a fluorometer sensor was installed on the CTD during the M84/3 cruise and a digital reversing thermometer was attached to the probe for quality checking. At almost all stations, water samples for dissolved oxygen were taken at different depths throughout the whole water column. The oxygen samples were analysed onboard using a potentiometric Winkler titration method. From three depth levels, depending on the vertical profile of the stations, water samples were also taken for calibration of the salinity values, and they were analysed onboard using a Guildline Autosal Salinometer. Data were processed applying the Seabird software and a Matlab post-processing package. Spikes were removed from all data by applying the instrumental and climatological range criteria backed up by visual checks. Profiles were then averaged every $1 \mathrm{dbar}$. The overall accuracies are within $0.002^{\circ} \mathrm{C}$ for temperature and 0.003 for salinity.

\subsection{Long-term oceanographic variability}

Vertical distributions of hydrographic data in the EM were examined to determine the long-term variability in the area since 1985. Three different approaches were applied:

1. Vertical distributions of temperature and salinity from the quasi-zonal section crossing the EM, from the Sicily Strait to the Levantine basin, were analysed by means of repeated surveys. We used data from all cruises throughout a trans-basin section: 1987 (Nellen et al., 1996), 1995 (Hemleben et al., 1996), 1999 (Pätzold et al., 2000), 2001 (Hemleben et al., 2003) and 2008 (Moutin et al., 2012). All these cruises took place as part 


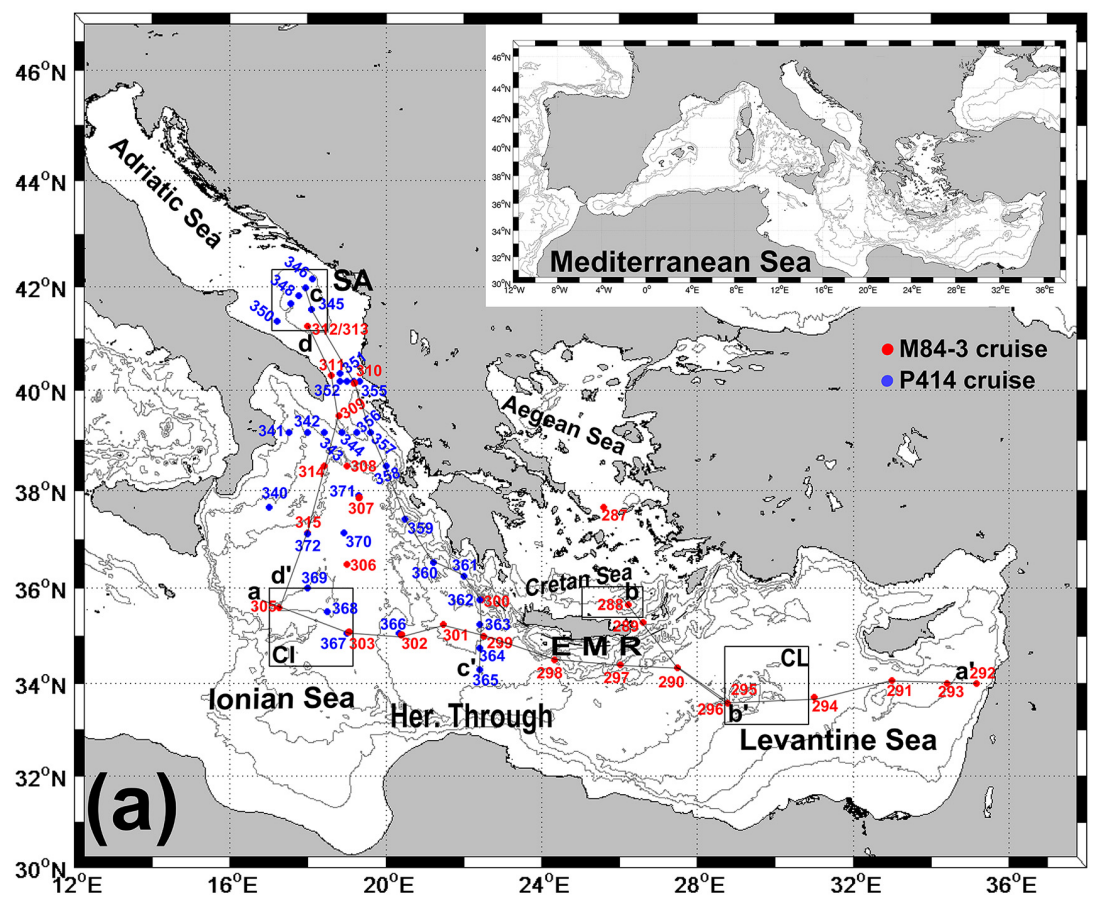

$\mathrm{Cl}=$ Central Ionian $\mathrm{CL}=$ Central Levatine $\mathrm{EMR}=$ Eastern Med. Ridge Her. Through $=$ Herodotus Through

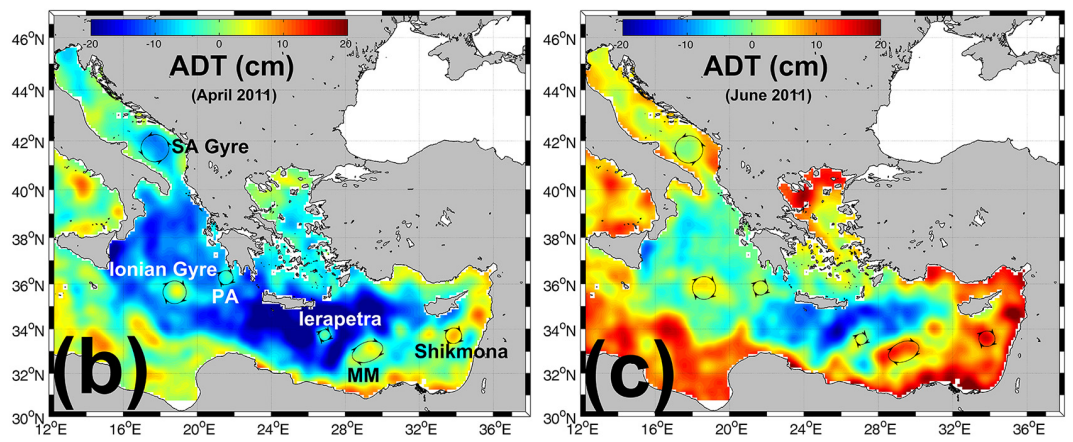

ADT = Absolute Dynamic Topography

SA = Southern Adriatic PA = Pelops Anticyclone $M M=$ Mersa Matruh Gyre

Figure 1. (a) CTD stations sampled in the Eastern Mediterranean Sea (EM) and Adriatic Sea during the M84/3 (red) and P414 (blue) cruises, and areas selected for the long-term analysis depicted. Hydrographic sections discussed in the text are identified as aa' to dd' . (b, c) Monthly absolute dynamic topography (ADT) map as the rectangles of the Eastern Mediterranean for April and June 2011. Principal structures are highlighted in the maps.

of collaborative investigations of the EM: the POEM (Physical Oceanography of the Eastern Mediterranean) research programme, EMTEC (Eastern Mediterranean Transient and Ecosystem monitoring), and the BOUM (Biogeochemistry from the Oligotrophic to the Ultraoligotrophic Mediterranean) experiment.

2. The long-term variability of the water mass structure in the EM was analysed on the basis of single profiles located in the central Ionian $\left[17-19^{\circ} \mathrm{E} / 34.5-36^{\circ} \mathrm{N}\right]$ and in the central Levantine $\left[29-31.5^{\circ} \mathrm{E} / 33-35^{\circ} \mathrm{N}\right]$; see Fig. 1.
3. The temporal evolution of the water mass structure in the CS and SA was analysed on the basis of thermohaline parameters collected within the areas depicted in Fig. 1 between 1985 and 2011. Some of the data come from the MEDATLAS database (see Maillard et al., 2002; Manca et al., 2004), while some were collected within the framework of European and German National projects. The Hellenic Centre of Marine Research (HCMR) provided some of the profiles obtained between 2006 and 2011 for the CS sampled during the E1M3A observatory maintenance cruises. Further infor- 
mation regarding the data set used for the SA can be found in Cardin et al. (2011).

For all data sets, derived parameters such as potential temperature, salinity and potential density were obtained from each original in situ temperature and conductivity profile. Hereinafter, temperature indicates potential temperature $(\theta)$, salinity is reported according to the practical salinity scale, density indicates the potential density excess $\left(\sigma_{\theta}\right)$, and the oxygen corresponds to the dissolved oxygen.

\subsection{Atmospheric forcing}

Air-sea heat fluxes at the air-sea interface were obtained from meteorological data such as mean sea level pressure, total cloud cover, wind speed at $10 \mathrm{~m}$ above the mean sea level, air temperature, dew point temperature at $2 \mathrm{~m}$ above the mean sea level, and skin temperature. These data were derived from the European Centre for Medium-Range Weather Forecasts (ECMWF) ERA-Interim data set with approximately $0.7^{\circ}$ spatial resolution, and downloaded on a Gaussian grid with $0.25^{\circ} \times 0.25^{\circ}$ resolution in latitude and longitude (interpolated by the ECMWF system from the original data). Total heat fluxes $\left(Q_{\text {net }}\right)$ were obtained as the sum of the heat flux components: the solar radiation (Qs) was calculated using the modified Reed formula (Schiano, 1996), the net long-wave radiation $\left(Q_{\mathrm{B}}\right)$ was obtained by applying the Bignami et al. (1995) formula, while the sensible $\left(Q_{\mathrm{H}}\right)$ and latent $\left(Q_{\mathrm{L}}\right)$ heat fluxes were obtained from the bulk aerodynamic formulas (Kondo, 1975). More information on the formulas applied, procedures and coefficients can be found in Cardin and Gačić (2003). Total winter heat fluxes were calculated as a time-integral for the period spanning 1 December to 31 March for the years 1985-2011. Normalized heat fluxes for each area were calculated applying

$Q_{\text {norm }}=\frac{\mathrm{X}-\mu}{\sigma}$,

where $Q_{\text {norm }}$ is normalized value; $X$ is individual $Q_{\text {net }}$ to normalize, $\mu$ is arithmetic long-term (1985-2011) winter average calculated from winter daily mean values and $\sigma$ is longterm (1985-2011) winter standard deviation.

\section{Thermohaline conditions}

The monthly average of the absolute dynamic topography (ADT) in the EM, referred to April and June 2011, are shown in Fig. 1b and c. Data are obtained from the Live Access Server of the AVISO web portal (http://las.aviso.oceanobs. com/las/getUI.do). The ADT is the sum of sea level anomaly and Synthetic Mean Dynamic Topography computed combining in situ drifter velocities and altimetry measurements. The error of the Synthetic Mean Dynamic Topography in the study area is in the range $1-3 \mathrm{~cm}$ (Rio et al., 2007). In this study, the ADT maps are used only to show the major circulation features in the upper thermocline, as some of the stations sampled during the M84/3 and P414 cruises were positioned at the edges or across dynamic structures that influence the water mass pathways. In the EM, several well-developed sub-basin-scale cyclonic or anticyclonic gyres, permanent or quasi-permanent, and interconnected by jets and meandering currents (Malanotte-Rizzoli et al., 1997), were observed in both April and June 2011.

Temperature and salinity along the quasi-zonal section crossing the EM, from the Sicily Strait to the Levantine basin, is shown in Fig. 2. In April 2011, the easternmost part of the transect was characterized by the presence of the Levantine Surface Water (LSW), which occupied the first $50 \mathrm{dbar}$ and showed high temperature $\left(\theta>18^{\circ} \mathrm{C}\right)$ and salinity $(S>39.15)$. Beneath this layer, a core of LIW with a salinity maximum of 39.24 on stations 293 (and 292, not shown) protruded westward (Fig. 2b), occupying the 150-350 dbar layer. Water characterized by $S>39.20$ and $\theta>17.50^{\circ} \mathrm{C}$ flowed out from the CS (St. 297) through the eastern Cretan Arc spreading into the Levantine Sea, and breaking the main LSW/LIW tongue with outcrops of the isohalines (see also Fig. 6). The westernmost part of the surface layer was mainly occupied by the AW within the upper $130 \mathrm{dbar}$ and confined by the 38.80 isohaline, contained within the Ionian circulation. AW propagated eastward along the pathway observed from the dynamic heights (ADT, Fig. 1b, c). Hence, from the analysis of Fig. 1b, c and Fig. 2 we can deduce that the AW veered due to the action of an intense anticyclonic mesoscale structure centred over the deepest area of the Ionian (at $\sim 19^{\circ} \mathrm{E}, 36^{\circ} \mathrm{N}$ ), the edge of which we sampled at stations 305,303 and 302 . AW intrusion into the Levantine basin is very variable and may depend on the circulation present in the Ionian (Gačić et al., 2010). In 2011 the NIG circulation was just reversing to cyclonic, as reported in Gačić et al. (2014). Previously, the main effect of $\sim 5$ years of anticyclonic NIG (2006-2010), when the AW meandered in the northernmost part of the Ionian Sea, was a general increase in salinity in the Levantine basin (see the long-term analysis and discussion in Sect. 4) and a general decrease in salinity in the SA.

The deep layer below $2500 \mathrm{dbar}$ (Fig. 2) is topographically divided into two by the EM Ridge (see its location in Fig. 1a, highlighted by the black dotted line). West of it, a large part of the Ionian basin was dominated by EMDW of Adriatic origin, still the coldest $\left(\theta<13.48^{\circ} \mathrm{C}\right)$, freshest $(S<38.73)$ and densest $\left(\sigma_{\theta} \approx 29.20 \mathrm{~kg} \mathrm{~m}^{-3}\right)$ water mass of the area, with the highest oxygen value $\left(204 \mu \mathrm{mol} \mathrm{kg}{ }^{-1}\right)$. The signature of the AdDW flowing out through the Otranto Strait was also found in profiles measured in the northernmost part of the Ionian, as will be shown later. East of it, the deepest part (below 2000 dbar) of the Levantine basin was filled by EMDW of Aegean origin, with similar $\sigma_{\theta}$ but slightly warmer and saltier $\left(\theta>13.6^{\circ} \mathrm{C}, S>38.78\right)$ than the EMDW found in 
a)

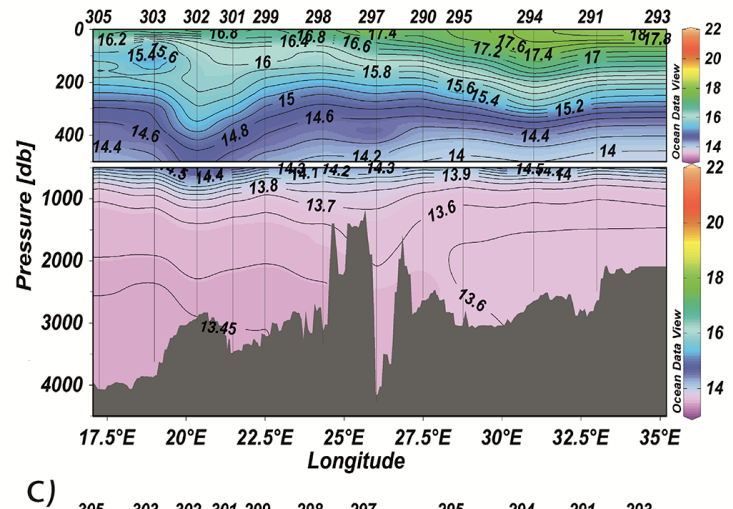

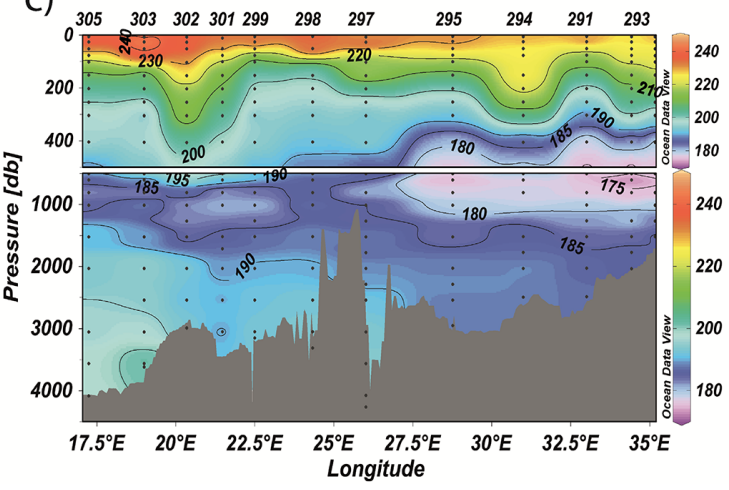

b)
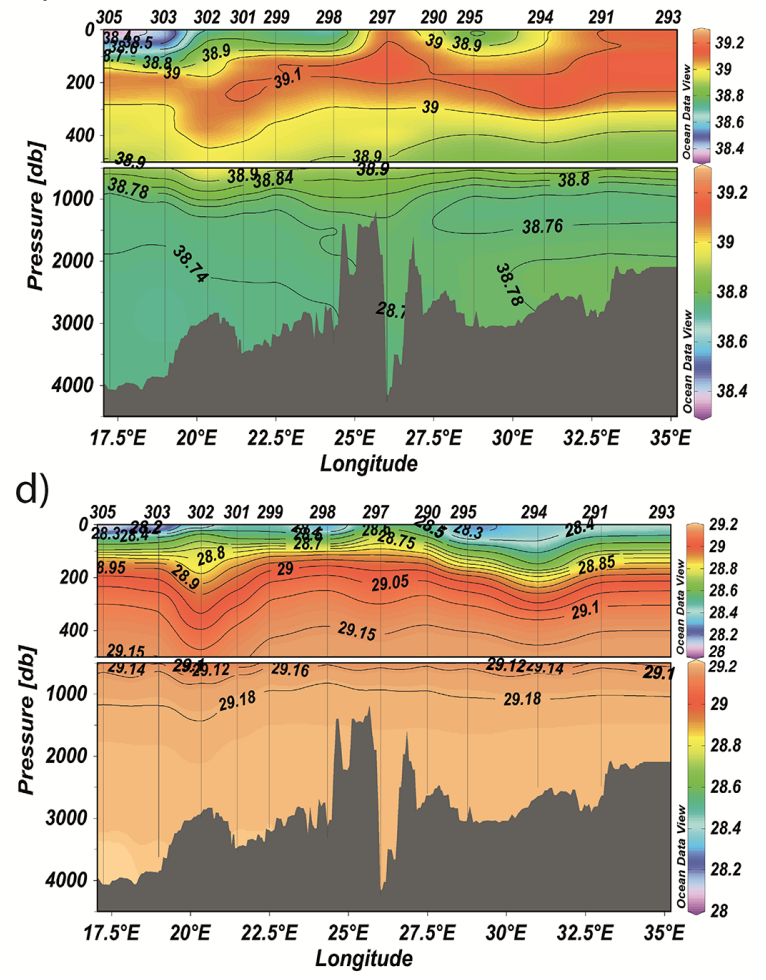

Figure 2. Water properties along a quasi-zonal east-west section in 2011 (marked as aa' in Fig. 1a): (a) temperature ( $\left.{ }^{\circ} \mathrm{C}\right)$, (b) salinity, (c) oxygen $\left(\mu \mathrm{mol} \mathrm{kg}^{-1}\right)$, (d) density $\left(\mathrm{kg} \mathrm{m}^{-3}\right)$. The upper panel highlights the first 500 dbar. Ierapetra and Mersa Matruh anticyclones can be identified at $\sim 26$ and $\sim 29^{\circ}$ E respectively.

the Ionian, and with lower oxygen levels (between 185 and $190 \mu \mathrm{mol} \mathrm{kg}^{-1}$ ) (see Fig. 2c).

The Cretan Sea water that flowed from the Kasos Strait showed salinity higher than $\sim 39.15$ occupying the first $250 \mathrm{dbar}$ and protruding like a tongue into the Levantine (Fig. 3, transect B). However, its area of influence was mainly confined to the north part of the EM Ridge; south of this area it encountered the AW at the surface, while it mixed with the LIW in the intermediate layer. Very dense water occupying the deep layer of the CS remained "isolated" by virtue of the presence of the sill. Notably, the densest water was found in the CS at station $288\left(\theta \approx 13.95^{\circ} \mathrm{C}, S \approx 39.06\right.$ and $\sigma_{0}>29.30 \mathrm{~kg} \mathrm{~m}^{-3}$; Hainbucher et al., 2014). This water remained blocked in the CS (see St. 289), filling the layer below 1000 dbar. The $T-S$ diagram (Fig. 3d) shows the characteristics of four stations along section $\mathrm{bb}^{\prime}$. Two of them (St. 290, green and St. 296, orange) are located in the Levantine basin and they revealed the typical long-lasting pronounced $T-S$ inversions already described in Hainbucher et al. (2014) for this cruise, and explained by Roether et al. (2014) in detail. This inversion was caused by a noticeable increase in temperature and salinity throughout the EM deep waters due to an anomalously abundant and dense outflow of water of Aegean origin produced during the EMT.
Station 289 (magenta) is located directly above the sill of the Kasos Strait where an inversion of higher temperature and salinity values at around $500 \mathrm{dbar}$ is found. This might indicate that two kinds of Cretan deep water mass, an older and a newer, are present in this area. Station 288 (red) is located in the Aegean Sea and reaches its minimum salinity values at around $1150 \mathrm{~m}$, indicating the presence of CDW at that level.

From its formation area westwards, the LIW pathway was directly influenced by the NIG and by the anticyclonic vortex present around $35.5^{\circ} \mathrm{N} / 19.0^{\circ} \mathrm{E}$ that trapped low-salinity waters in its centre, as seen in Figs. 1b, c and 3. There, the LIW bifurcated: one branch flowed westward directly to the Sicily Channel while the other one flowed northwards along the eastern shelf-break of the Ionian. To describe the LIW pathway into the northern Ionian and into the Adriatic, temperature, salinity and density meridional sections along transect $\mathrm{cc}^{\prime}$ are presented in Fig. 4. The LIW seems to be influenced by the Pelops anticyclone (PA in Fig. $1 \mathrm{~b}$, at $\sim 36.5^{\circ} \mathrm{N}$ ), as revealed by the down-sloping of the isopycnals, and by the water exiting the CS through the Antikythera Strait (right part of the panels). The southernmost stations of the transect showed the presence of the AW in the first $100 \mathrm{dbar}$ while the rest of the stations showed the LIW spreading northward into the Ionian basin as a warm $\left(\theta \approx 15.0^{\circ} \mathrm{C}\right)$ and 
a)

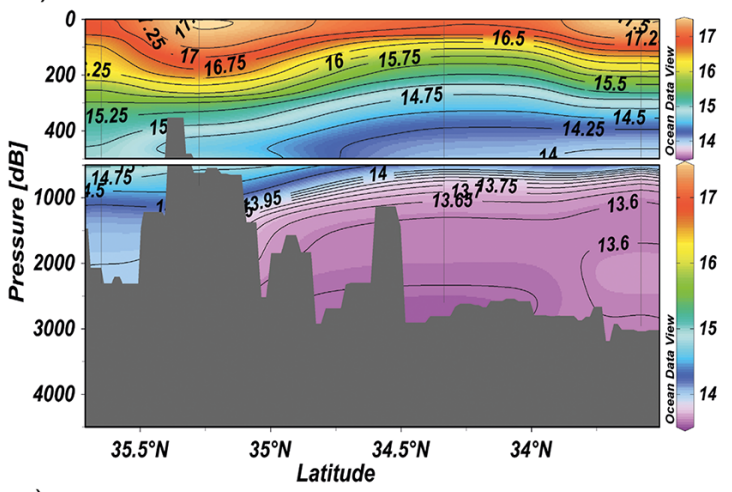

c)

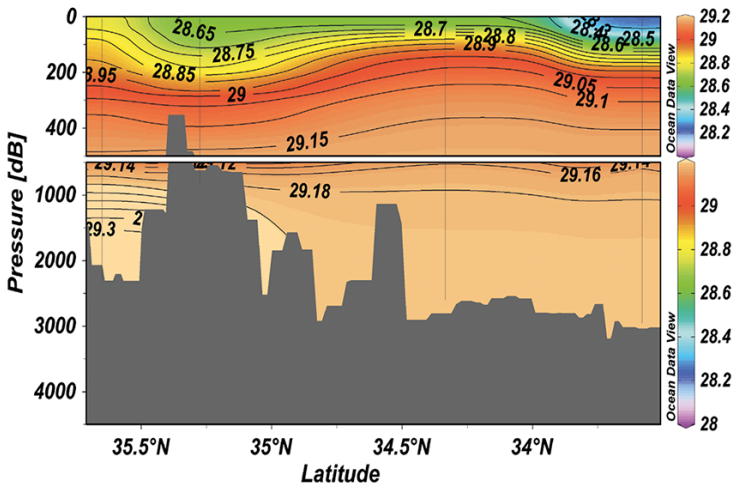

b)

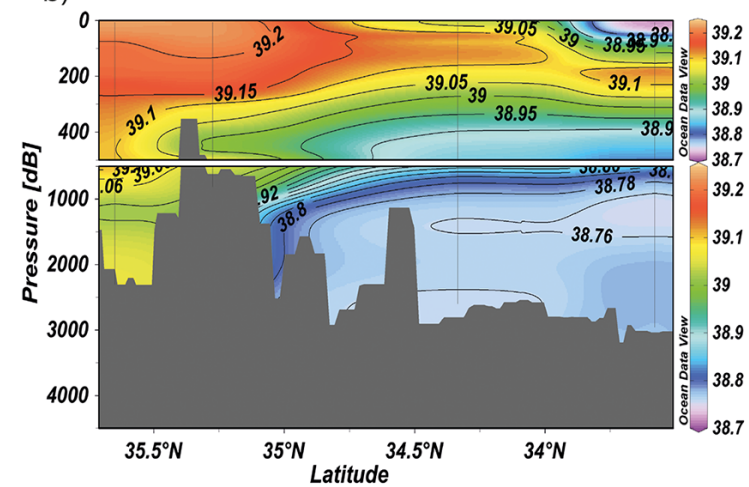

d)

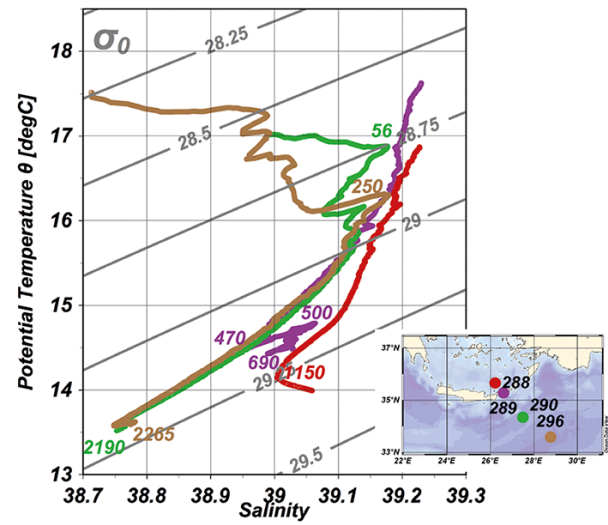

Figure 3. Water properties along the section crossing the Kasos Strait (marked as bb' in Fig. 1a): (a) temperature $\left({ }^{\circ} \mathrm{C}\right)$, (b) salinity, (c) density $\left(\mathrm{kg} \mathrm{m}^{-3}\right)$, (d) $T-S$ diagram of the stations considered on the transect. Positions of salinity inversions along the water column are indicated in dbar in the diagram and coloured similar to the station profile. The upper panels of (a), (b) and (c) highlight the first $500 \mathrm{dbar}$.

a)

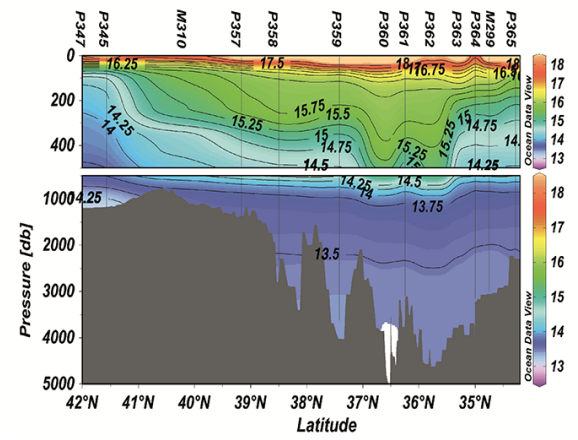

b)

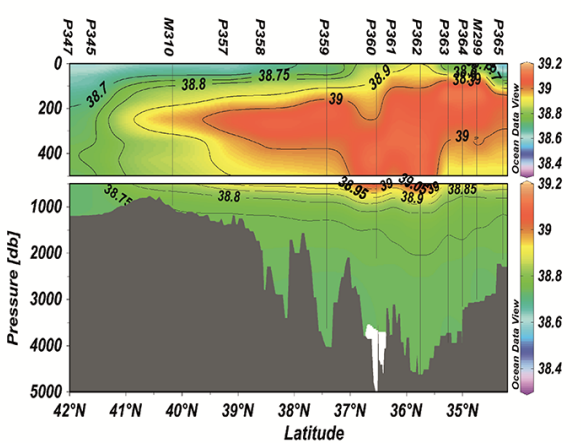

c)

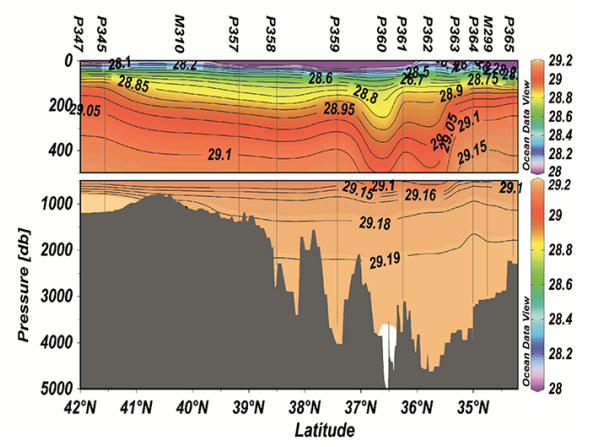

Figure 4. Water properties along the eastern longitudinal section (N-S) (marked as $\mathrm{cc}^{\prime}$ in Fig. 1a) following the traditional path of the saline core water towards the Adriatic Sea: (a) temperature $\left({ }^{\circ} \mathrm{C}\right)$, (b) salinity, (c) density $\left(\mathrm{kg} \mathrm{m}^{-3}\right)$. The upper panels highlight the first $500 \mathrm{dbar}$. Poseidon P414 stations are identified by the letter P and Meteor M84/3 by the letter M. Pelops anticyclone can be identified at $\sim 36.5^{\circ} \mathrm{N}$.

saltier (salinity maximum ranging from 38.8 to 39 ) tongue of water. At the time of the cruises (April and June) the LIW core $(S>=39.0)$ did not enter the Adriatic through the Strait of Otranto, and only water with $S<38.80$ was advected over the Otranto sill, occupying the intermediate horizon in the Adriatic. The deep layer ( $>800 \mathrm{dbar})$ of the SA (Fig. 5) was filled with AdDW ( $\theta \approx 13.07^{\circ} \mathrm{C}, S \approx 38.73$, $\sigma_{\theta} \approx 29.275 \mathrm{~kg} \mathrm{~m}^{-3}$ ). However, only a part of the AdDW overflowed the Otranto sill (depth $\sim 800 \mathrm{dbar}$ ), cascading along the Ionian continental margin towards the deep layer of the central Ionian. The intense mixing affecting the AdDW branches sinking toward the abyssal plain of the Ionian Sea leads eventually to a warming and salinification (Manca et al., 2003; Hainbucher et al., 2006; Bensi et al., 2013) as well 

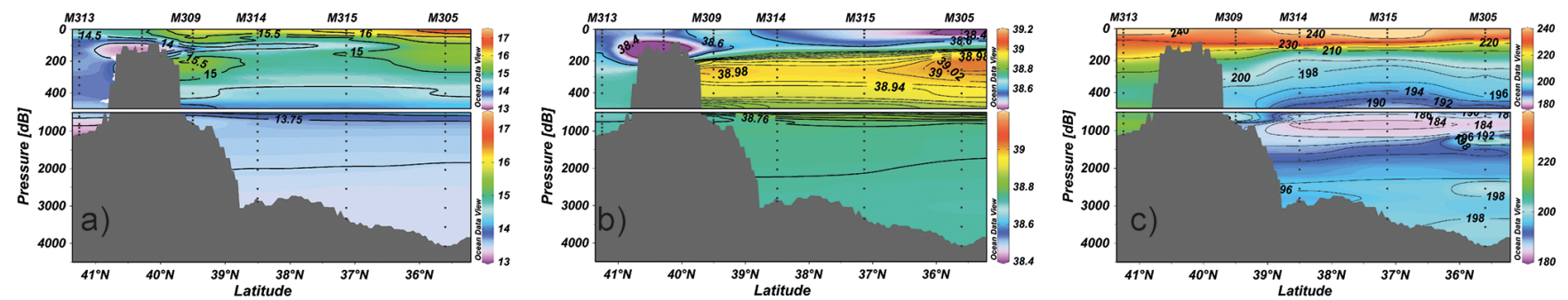

Figure 5. Water properties along the western longitudinal section $(\mathrm{N}-\mathrm{S})$ in the Ionian (marked as dd $\mathrm{d}^{\prime}$ in Fig. 1a): (a) temperature $\left({ }^{\circ} \mathrm{C}\right)$, (b) salinity, (c) oxygen $\left(\mu \mathrm{mol} \mathrm{kg}{ }^{-1}\right)$. The upper panels highlight the first $500 \mathrm{dbar}$. Meteor M84/3 stations are identified by the letter M.

as to a reduction in the relatively high dissolved oxygen content associated with the AdDW.

The western meridional (N-S) section dd' (Fig. 5) links the SA and Ionian Seas along the Italian coast, ending at the western edge of the quasi-zonal transect crossing the EM. This field distribution complements the information inferred from Fig. 4, indicating that the LIW did not enter the Adriatic, while the cyclonic circulation observed is coherent with the ADT distribution shown in Fig. 1b and c. High-salinity waters characterized the intermediate layer spreading from east to west in a cyclonic circulation with the core of the LIW located between 200 and $300 \mathrm{dbar}$, whereas low-salinity waters were confined to the surface layer along almost the whole section shown from the northern part of transects (b) and (c), depicted in Figs. 4 and 5. The latter also shows two cores of high salinity water, the first located at St. M309 and the second at St. M305, both catching a less diluted signal of the LIW spreading westward from the Levantine. Beneath the LIW, low-salinity waters (38.72) with relatively high oxygen content $(198 \mu \mathrm{mol} \mathrm{kg}-1)$ filled the deepest part of the central Ionian. They can be attributed to relatively fresh and recently ventilated water of Adriatic origin. The oxygen minimum was located in the layer 1000-1300 dbar, with values around $180 \mu \mathrm{mol} \mathrm{kg}^{-1}$, showing that this layer was scarcely renewed.

Maps of salinity distributions (Fig. 6a) at $100 \mathrm{dbar}$ and at the isopycnal surface of $\sigma_{\theta}=29.05 \mathrm{~kg} \mathrm{~m}^{-3}$ (Fig. 6b), i.e. the typical horizon of the LIW (Malanotte-Rizzoli et al., 1997), provide evidence of the major water masses occupying the basin from the Sicily Channel to the Cretan Passage and their circulation patterns. The AW entered the Ionian Sea from the Sicily Channel and protruded towards east and north, occupying an extended portion of the west half of the Ionian basin. A front running from 36 to $40^{\circ} \mathrm{N}$ separated lowsalinity waters of Atlantic origin $(<38.45)$ from Ionian Surface Waters (38.60). This pattern confirms that the anticyclone positioned at $19^{\circ} \mathrm{E}$ (Ionian gyre in Fig. $1 \mathrm{~b}$ and c) acts as a sorting point from which the AW divides into two branches, one flowing to the east and the other proceeding northward. Bifurcated pathways of LIW were also recognizable from the salinity distribution at $29.05 \mathrm{~kg} \mathrm{~m}^{-3}$ (Fig. 6b): (i) the tongue defined by $S \sim 39.0-39.05$ spread directly from the Cretan
Passage towards the Sicily Channel; (ii) the other branch of LIW was embedded in the NIG, and extended north of the Peloponnesus peninsula along the eastern border of the Ionian basin. On its way towards west and northwest the LIW mixed with the surrounding waters, decreasing its salinity.

\section{Long-term variability in the Eastern Mediterranean}

The long-term variability along the quasi-zonal section, from the Sicily Strait to the Levantine basin, is discussed here through the analysis of the vertical distributions of temperature and salinity sampled during six repeated surveys carried out in different oceanographic stages of the EMT: 1987, which represents the pre-EMT phase; 1995 when the EMT was in full swing - i.e. a large amount of Aegean-derived deep water was still deposited in the near-bottom waters around the Cretan Arcs and the Adriatic salinity maximum decreased; 1999 and 2001 showing the evolution of the EMT; and, finally, data from cruises carried out in 2008 and 2011 which reflect the more recent oceanographic situation. Figures 7 and 8 show the vertical distributions of temperature and salinity respectively. For a detailed discussion on the major findings from the cruises carried out in 1987, 1995 and 1999, the reader is referred to the works by Klein et al. (1999, 2000), Malanotte-Rizzoli et al. (1999), Manca et al. (2003) and Roether et al. (2007). A similar approach was used by Touratier and Goyet (2011) to determine the distributions of properties $(\theta, S$, oxygen) along a west-east transect in the EM, but considering all stations (from the Medar/Medatlas II database) within a band of $200 \mathrm{~km}$ and for years 2000-2001.

Data from the M5/6 cruise in 1987 show the hydrographic conditions prior to the EMT in the Ionian and Levantine basins, when the AdDW was clearly the main contributor to the EMDW (Figs. 7a and 8a). This distribution is considered a reference for the climatological state of the EM (Schlitzer et al., 1991). Indeed, the deep western and central Ionian showed a temperature of $13.30^{\circ} \mathrm{C}$ and salinities lower than 38.68. On the other hand, observations conducted during the EMT phase, in 1995 and 1999 (Figs. 7b, c and $8 \mathrm{~b}, \mathrm{c}$ respectively), revealed the presence of Aegean waters outside the Cretan Passage, with large salinity and tempera- 

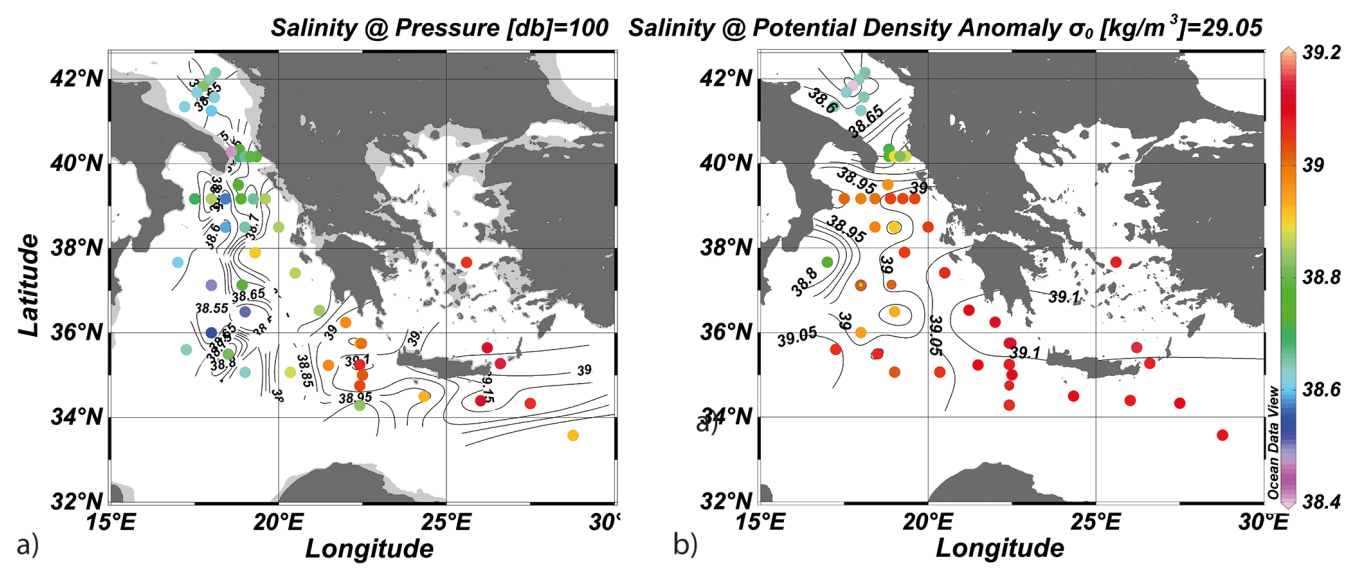

Figure 6. Horizontal distribution of salinity at $100 \mathrm{dbar}$ (a) and on the $29.05 \mathrm{~kg} \mathrm{~m}^{-3}$ isopycnal (b).

ture values, lying at the deepest layer of the EM. Enhanced salinity and temperature relative to 1987 (values higher than 38.84 and $13.60^{\circ} \mathrm{C}$ ) were already ubiquitous in early 1995 (Roether et al., 2007), with the exception of the western Ionian deep layer which was still occupied by low-salinity and low-temperature waters $\left(S<38.68, \theta<13.30^{\circ} \mathrm{C}\right)$. In 1995 , waters of Aegean origin at the Cretan Passage were clearly recognizable by a dome of the ventilated bottom waters associated with $\theta>14.0^{\circ} \mathrm{C}$ and $S>38.78$. An analogous distribution was found in 1999 (see Theocharis et al., 2002; Manca et al., 2003) at the Cretan Arc and at the easternmost part of the Levantine basin (Figs. 7d and 8d), blocked by the bathymetry constraint of the EM Ridge. In the same years, signs of new EMDW of Adriatic origin were already evident in the western continental slope of the Ionian Sea, i.e. indicating that a major change occurred between 1999 and 2003 in the abyssal part of the Ionian basin, where AdDW returned gradually to become the principal contributor to the EMDW (Hainbucher et al., 2006; Manca et al., 2006; Rubino and Hainbucher, 2007; Bensi et al., 2013). In 2008 (Figs. 7e and 8e) only the Levantine basin was still under the influence of the warm and saline CDW that overflowed during the EMT, whilst the EMDW that resided in the Ionian abyssal layer was influenced by more recent AdDW with modified properties, being warmer and saltier $\left(\theta=13.40^{\circ} \mathrm{C}, S=38.72\right)$ than in the past. These results are consistent with the tendency toward the warming of and salinification of the AdDW pointed out by Rubino and Hainbucher (2007) and seen also in 2011 (Figs. 7f and 8f) when, in general, temperature and salinity in the abyssal layer of the Ionian Sea $\left(\theta \approx 13.40^{\circ} \mathrm{C}, S \approx 38.75\right)$ indicated almost everywhere a continuous relaxation of the EMT since the early 1990s.

The analysis of the upper layer $(0-500$ dbar $)$ in Figs. 7 and 8 showed that the decadal variability of the Ionian and Levantine thermohaline properties is strongly related to the variability of the AW pathway, which in turn is influenced by the circulation regime in the Ionian Sea. In the last decades, different regimes alternated, leading to an increase (when AW was transported toward the Ionian basin by anticyclonic circulation) and to a decrease (when AW was transported toward the Levantine basin by cyclonic circulation) in the salinity in the Levantine basin. This variability is clearly evident in Fig. 8, where the salinity of the upper thermocline, especially in the Levantine basin, appears to oscillate on multiannual or decadal scales. A relative minimum in salinity was evident in 1987 (Fig. 8a) and was followed by an increase in 1995. At the end of 1980s the AW flow in the Ionian increased and an anticyclonic circulation up to $39^{\circ} \mathrm{N}$ arose (Malanotte-Rizzoli et al., 1997). This anticyclonic period lasted until 1996. The two salinity distributions in 1987 and 1995 (Fig. 8a and b, respectively) represent the limits of a period during which the salinity progressively increased.

Different mechanisms acting separately or even in combination could potentially explain part of such variability. Gačić et al. (2010, 2011) and Theocharis et al. (2014) showed that internal mechanisms seem to prevail over the atmospheric forcing in engaging the reversal of the circulation in the Ionian, which in turn modifies the position of the Atlantic-Ionian Stream responsible for the salinity distribution in the EM. In contrast, Pinardi et al. (2013) suggested that the reversal was wind driven.

The massive production and outflow of CDW was the principal manifestation of the EMT. To observe the evolution of the thermohaline properties of the water column in the CS (Fig. 9, upper panel) and in the SA (Fig. 9, lower panel), Hovmöller time diagrams of the thermohaline properties during the period 1986-2011, based on all CTD profiles sampled in the areas indicated in Fig. 1a, were obtained. Special attention was given to the density $=29.20 \mathrm{~kg} \mathrm{~m}^{-3}$; this is the maximum density recorded in 1987 at the reference level of 1300 dbar in the proximity of the Kasos Strait, and it is considered the threshold density for filling the deep layers of the EM. The 900 and 800 dbar levels highlighted represent 

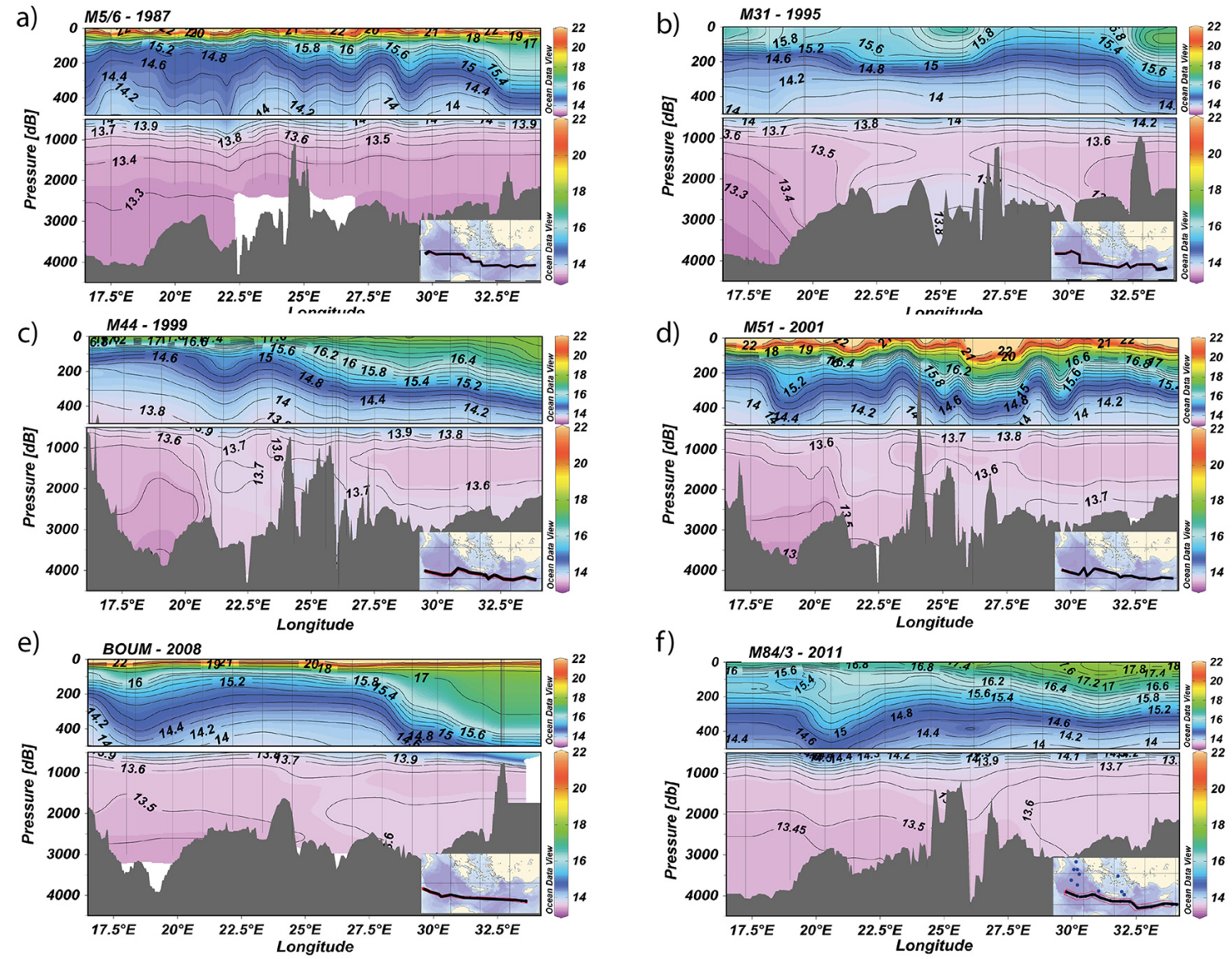

Figure 7. Sections of temperature $\left({ }^{\circ} \mathrm{C}\right)$ (see inset map) in (a) 1987 (Meteor M5/6), (b) 1995 (Meteor M31/1), (c) 1999 (Meteor M44/4), (d) 2001 (Meteor M51/2), (e) 2008 (BOUM) and (f) 2011 (Meteor M84/3). The upper panels highlight the first $500 \mathrm{dbar}$.

the outflow levels above the Kasos and Otranto sills, respectively.

The time evolution of salinity in the CS shows, firstly, a remarkable increase in a large part of the water column (from $400 \mathrm{dbar}$ to the bottom) in the period 1985-1992. As demonstrated by Theocharis et al. (1999), in the subsequent period (1992-1994) the strong decrease in temperature due to the very cold winters in 1992 and 1993 caused the accumulation of a huge amount of dense water $\left(\sigma_{\theta}>29.20 \mathrm{~kg} \mathrm{~m}^{-3}\right)$, as shown by the rapid rise of the $29.20 \mathrm{~kg} \mathrm{~m}^{-3}$ isopycnal (Fig. 9c, upper panel). At the same time, in the SA (Fig. 9c, lower panel) the salinity was $<38.70$ from $200 \mathrm{dbar}$ to the outflow depth, slightly increasing until $1990(S>38.70)$, and then decreasing until about 1997 . The $29.20 \mathrm{~kg} \mathrm{~m}^{-3}$ isopycnal depth rose from $600 \mathrm{dbar}$ (in 1985) to about $250 \mathrm{dbar}$ (in 1992). The maximum density observed at the overflow depth was $29.25 \mathrm{~kg} \mathrm{~m}^{-3}$.

In the period 1992-1995, the CS density at the outflow level of the Kasos Strait remained higher than $29.25 \mathrm{~kg} \mathrm{~m}^{-3}$ and corresponds to the period of the most intense and continuous outflow of the new CDW into the Levantine basin (Theocharis et al., 1999). In the SA, in contrast, density rapidly decreased to values $\approx 29.20 \mathrm{~kg} \mathrm{~m}^{-3}$ only in the deepest portion (650-800 dbar) of the water column involved in the exchange with the Ionian Sea. In this period, the EMDW of Adriatic origin present in the Ionian Sea and in the Levantine was progressively displaced by the new denser CDW.

Our analysis confirms what was hypothesized by Roether et al. (2007) regarding the evolution of the Cretan water thermohaline properties post-EMT (from 1995) at the outflow level -i.e. that due to the slow deepening of the $29.20 \mathrm{~kg} \mathrm{~m}^{-3}$ isopycnal, the density levels exceeded pre-EMT values for several years. The strong CDW outflow was compensated for by an increased inflow of surface Levantine waters and by the Transitional Mediterranean Water, which in the CS was traceable by a salinity minimum (Theocharis et al., 1999) between 200 and 400 dbar in 1993-1995, progressively deepening and losing its characteristics around the second half of the 2000s. The presence of Transitional Mediterranean Water presumably inhibited further significant vertical mixing and dense water production after 1993.

As shown by Klein et al. (2000) and Cardin et al. (2011), the decrease in salinity at the intermediate level in the SA reached a minimum in 1995, after which the salinity started 

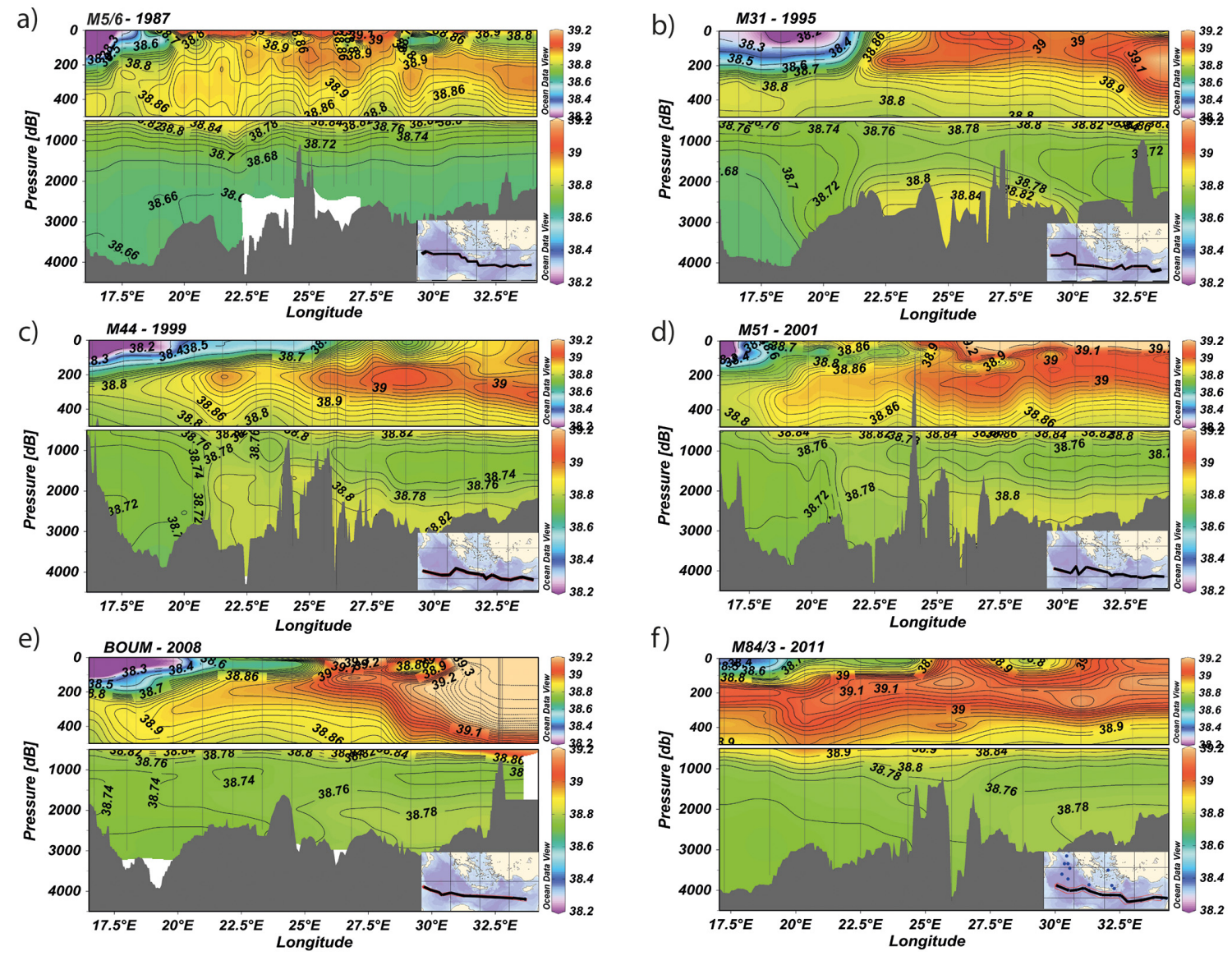

Figure 8. Sections of salinity (see inset map) in (a) 1987 (Meteor M5/6), (b) 1995 (Meteor M31/1), (c) 1999 (Meteor M44/4), (d) 2001 (Meteor M51/2), (e) 2008 (BOUM) and (f) 2011 (Meteor M84/3). The upper panels highlight the first 500 dbar.

to increase again until 2005. It is evident from Fig. 9 that sufficient preconditioning was established to resume the AdDW production during the first half of the 2000s. This was the result of a massive import of LIW and Cretan Intermediate Water (CIW) from the Ionian. However, it was only after 2005 that the AdDW at the overflow depth at the Otranto sill regained a density $>29.20 \mathrm{~kg} \mathrm{~m}^{-3}$.

During the last part of the period studied, namely from 2005 to 2011, salinity at the intermediate level in the CS continuously increased, reaching absolute maximum values of $>39.10$ in 2011. A concomitant temperature increase that prevented effective convection able to produce as much dense water to fill the deep Cretan basin was observed. In the same period in the SA the salinity of the whole water column decreased, as did the density after a relative maximum $\left(29.20 \mathrm{~kg} \mathrm{~m}^{-3}\right.$ at $\left.600 \mathrm{dbar}\right)$ in 2006.

The role of the preconditioning, linked to the basin circulation, in promoting the alternation of dense water formation in the CS with that in the SA is important, but the relevance of the air-sea interaction cannot be neglected. Therefore, interannual variability in the normalized heat flux $\left(Q_{\text {norm }}\right)$ was analysed in the two sites for the period December to March
(Fig. 10). The general behaviour in the two sites was similar. Particularly noteworthy is the heat loss which occurred in the winters 1991-1992 and 1992-1993 in the CS and which triggered the active phase of the EMT. Another period of intense winter heat loss was from 2002 to 2006, for both sites. In this period, in the SA both preconditioning and heat loss were favourable to the AdDW production, whilst in the CS the presence of the above-mentioned Transitional Mediterranean Water counteracted the noticeable heat loss reported in Fig. 10. From 2007 to 2011 neither basin was subject to significant heat loss. The increased temperature in the CS and the decreased salinity in the SA made the situation in the two basins very similar in terms of the density at their own outflow depths. Also, thermohaline properties in the CS were still very different from those recorded in the pre-EMT phase.

The alternating capability of the Cretan and Adriatic seas in producing dense water by means of the internal salt redistribution between the Ionian Sea and Levantine basin has already been pointed out by Gačić et al. (2011), Theocharis et al. (2014) and Velaoras et al. (2014). Our comparative analysis also suggests that the evolution of thermohaline proper- 

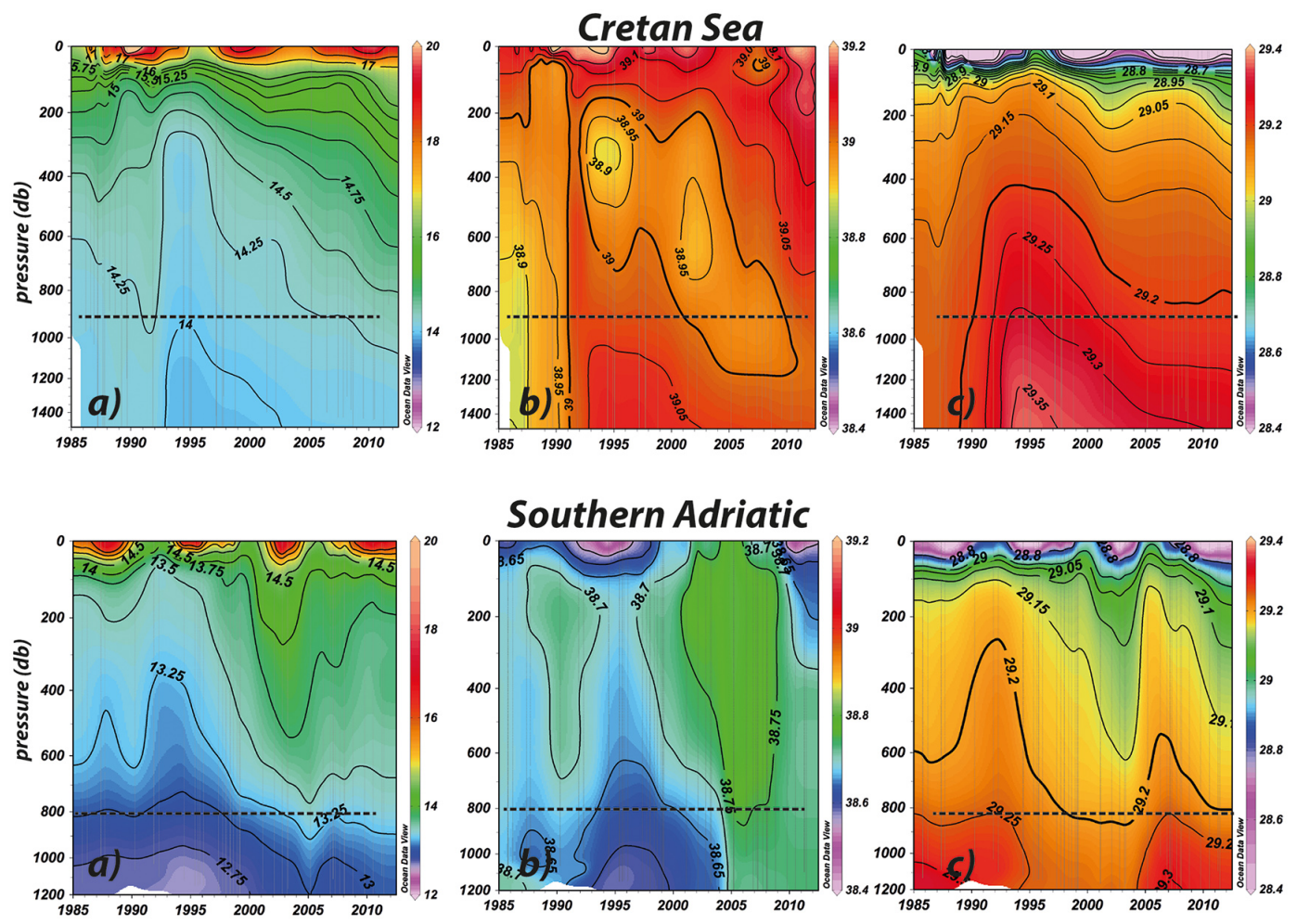

Figure 9. Hovmöller time diagrams of temperature, salinity and density for the period 1986-2011 for the Cretan Sea and Southern Adriatic. The selected areas are shown in Fig. 1a. The 900 and 800 bar levels highlighted represent the outflow level above the Kasos and Otranto sills, respectively. The $y$-axes are expanded at the top.

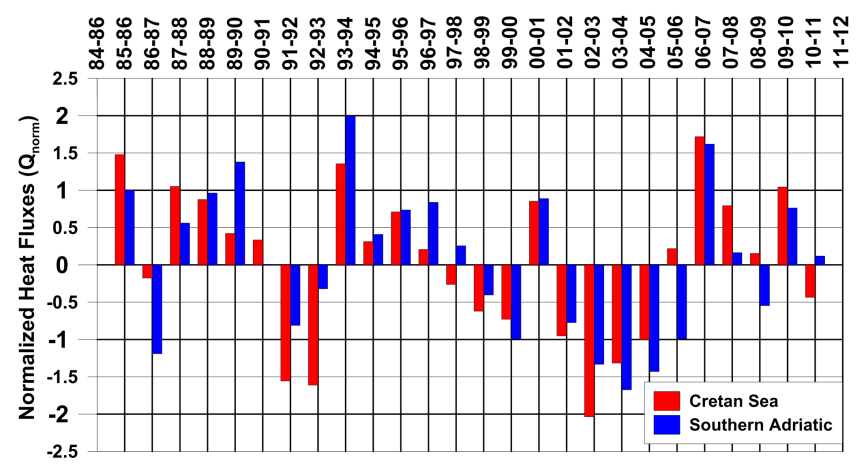

Figure 10. Normalized winter heat fluxes between 1985 and 2011 for the southern Adriatic (SA; blue) and the Cretan Sea (CS; red) with respect to their own mean. Winter period is defined as December to March. The selected areas are shown in Fig. 1a.

ties of the two potential dense water source areas is subject to the complex interactions among preconditioning, air-sea interactions, and local dynamics and circulation.

The spatial and temporal evolution of the water mass structure was also analysed through the comparison of vertical profiles of temperature and salinity within two areas: the central Ionian and the central Levantine (see Fig. 11a and $b$ for vertical profiles and Fig. 1 for the location of the areas). This analysis includes the data from cruises already discussed in the previous paragraph. The inset graphs enhance the oceanographic characteristics for the deep layer below $1500 \mathrm{dbar}$. Salinity and temperature profiles for both areas (Fig. 11a and b, zoomed areas) are mostly indicative of changes in the water mass structure related to the EMT. In 1987, the central Levantine below 2500 dbar showed a vertical homogeneity in temperature and salinity in the ranges $\approx 13.34^{\circ} \mathrm{C}$ and $\approx 38.66$, respectively. In 1991, a slight increase in salinity from $\sim 500$ dbar down to the bottom was seen. In 1995, the salinity increase was remarkable, especially below $2300 \mathrm{dbar}$ where it jumped from 38.71 to $\sim 38.84$ because of the new dense CDW outflow (Roether et al., 1996). Its signature was tracked until 2007, when the salinity started to decrease. Meanwhile, in the central Ionian the salinity continued to increase, the abyssal layer being filled by newly formed AdDW, saltier and warmer; this was still evident in 2011. The most recent data (2008-2011) in the deep layer in the central Levantine show a salinity and temperature decrease, probably a result of the basin internal mixing (Roether et al., 2014). 

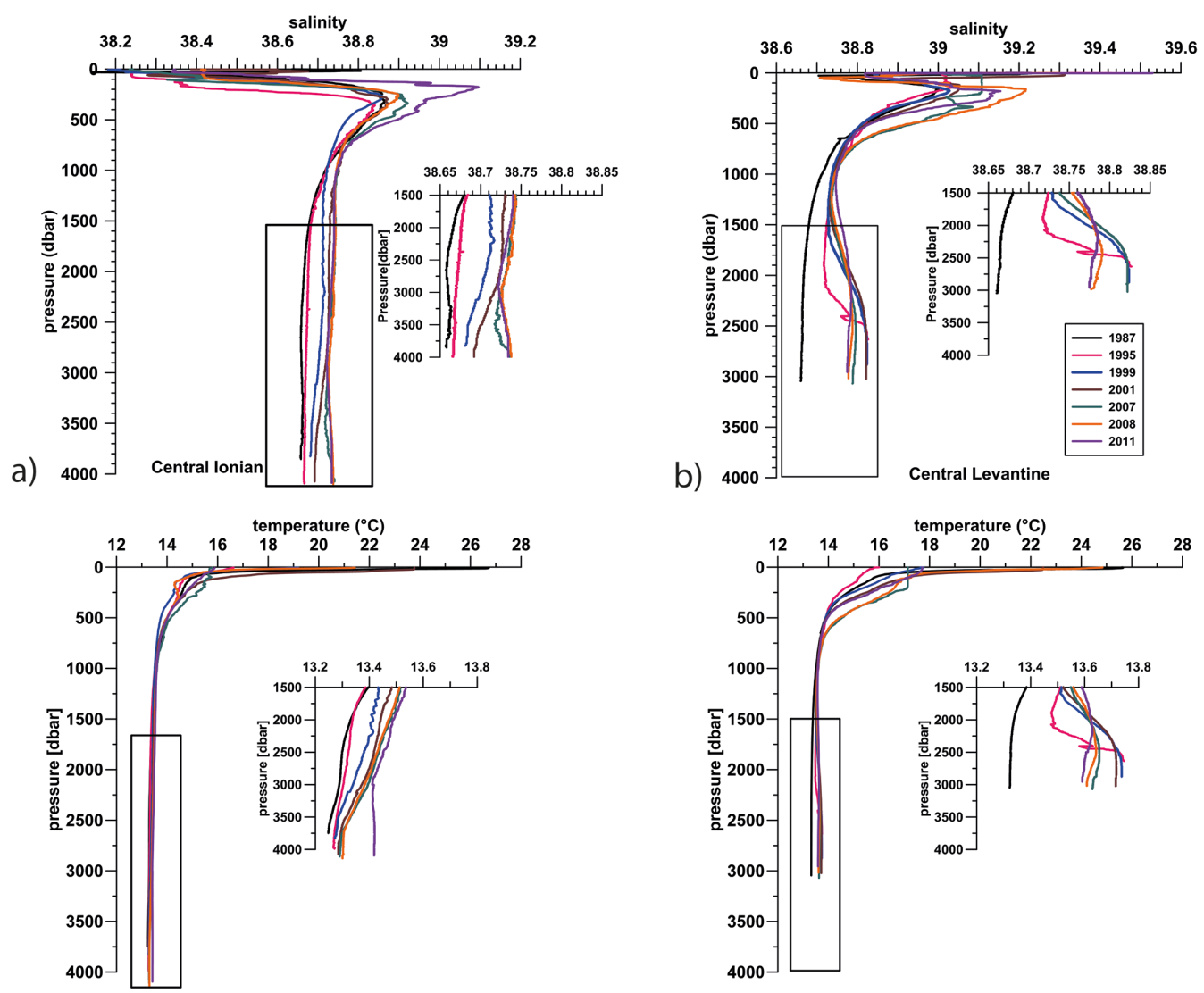

Figure 11. Vertical profiles of temperature $\left({ }^{\circ} \mathrm{C}\right)$ and salinity in the central Levantine (a) and central Ionian (b). For graphical purposes the salinity scales have the same unit length but range from 38.6 to 39.6 for the central Levantine, and from 38.2 to 39.2 for the central Ionian. The selected areas are shown in Fig. 1a.

\section{Conclusions}

This paper discusses data collected in 2011 during the $M e$ teor M84/3 (April 2011) and the Poseidon P414 (June 2011) cruises in the context of the spatial and temporal evolution of the large-scale oceanographic properties of the EM during the last three decades. Additionally, we discussed the interannual variability of the preconditioning and air-sea interaction (heat fluxes) in the two main dense water source areas for the EM, i.e South Adriatic and Cretan Seas.

Our results, which are the most recent analysis for the whole EM, reveal that the thermohaline properties in the study area were still far from those observed in the pre-EMT phase (1987). The 2011 oceanographic conditions in the deep layers of the central Ionian, however, lie between the thermohaline characteristics of the EMT and those of the pre-EMT phase, indicating a possible slow return towards the latter.

The abyssal layer of the central Ionian experienced the effect of a post-EMT phase, which started in about 2003, characterized by the arrival of newly formed AdDW waters, completely different from the recent past in that they are saltier and warmer. In the following years, this new EMDW of Adri- atic origin seemed to have propagated towards the abyssal Levantine basin.

This study highlights the relationship between the hydrological property distribution of the upper layer in the Levantine basin and the alternate circulation regimes in the Ionian, which modulates the salinity distribution in the EM.

The comparative analysis of the evolution of the thermohaline properties in the two potential dense-water source areas, SA and CS, demonstrates that, as far as dense-water accumulation is concerned, the alternation of the two sites is strongly influenced by the preconditioning driven by the reversal of the NIG. Nevertheless, the role of the air-sea interaction and the local dynamics should be taken into account in assessing the decadal variability of the EM thermohaline cells.

Acknowledgements. The authors would like to thank the captains and crews on the research vessels RV Meteor and RV Poseidon for their cooperation during the cruises. Special thanks to George Petihakis and the Hellenic National Oceanographic Data Centre (HNODC) for providing the CTD casts between 2005 and 2010 near the E1M3A observatory and in the Cretan Sea. Thanks go to Louis Prieur and Thierry Moutin for kindly providing the CTD of the BOUM cruise. The Meteor cruise M84/3 was 
supported by a grant from the Deutsch Forschungsgemeinshaft Senatskommision für Ozeanographie (DFG), TA 311/3-1. Funding from the University of Hamburg supported the Poseidon P414 cruise. V. Cardin and G. Civitarese thank the CIESM for supporting their participation in the Meteor Cruise. The Italian Ministry of Education, University and Research (MIUR) supported this research under the RITMARE (Ricerca ITaliana per il MARE) and MedGES (Studio integrato dell'influenza dei processi fisici e dei fattori antropici sullo stato degli ecosistemi costieri e profondi del Mediterraneo Centrale) national projects. The Topic Editor is grateful to the two anonymous referees for their contributions which have helped to greatly improve the quality of this paper.

Edited by: S. Sparnocchia

\section{References}

Bensi, M., Rubino, A., Cardin, V., Hainbucher, D., and ManceroMosquera, I.: Structure and variability of the abyssal water masses in the Ionian Sea in the period 2003-2010, J. Geophys. Res., 118, 1-13, doi:10.1029/2012JC008178, 2013.

Bignami, F., Marullo, S., Santoleri, R., and Schiano M. E.: Longwave radiation budget in the Mediterranean Sea, J. Geophys. Res., 100, 2501-2514, 1995.

Cardin, V. and Gačić, M.: Long-term heat flux variability and winter convection in the Adriatic Sea, J. Geophys. Res., 108, 8103, doi:10.1029/2002JC001645, 2003.

Cardin, V., Bensi, M., and Pacciaroni, M.: Variability of water mass properties in the last two decades in the Southern Adriatic Sea with emphasis on the period 2006-2009, Cont. Shelf Res., 31, 951-965, doi:10.1016/j.csr.2011.03.002, 2011.

D'Ortenzio, F. and Prieur, L.: The upper mixed layer, in: Life in the Mediterranean Sea: A look at habitat changes, edited by: Stambler, N., Nova Science Publisher, 127-156, 2012.

Gačić, M., Borzelli, G. L. E., Civitarese, G., Cardin, V., and Yari, S.: Can internal processes sustain reversals of the ocean upper circulation? The Ionian Example, Geophys. Res. Lett., 37, L09608, doi:10.1029/2010GL043216, 2010.

Gačić, M., Civitarese, G., Eusebi Borzelli, G. L., Kovačević, V., Poulain, P.-M., Theocharis, A., Menna, M., Catucci, A., and Zarokanellos, N.: On the relationship between the decadal oscillations of the Northern Ionian Sea and the salinity distributions in the Eastern Mediterranean, J. Geophys. Res., 116, C12002, doi:10.1029/2011JC007280, 2011.

Gačić, M., Civitarese, G., Kovačević, V., Ursella, L., Bensi, M., Menna, M., Cardin, V., Poulain, P.-M., Cosoli, S., Notarstefano, G., and Pizzi, C.: Extreme winter 2012 in the Adriatic: an example of climatic effect on the BiOS rhythm, Ocean Sci., 10, 513-522, doi:10.5194/os-10-513-2014, 2014.

Hainbucher, D., Rubino, A., and Klein, B.: Water mass characteristics in the deep layers of the western Ionian basin observed during May, Geophys. Res. Lett., 33, L05608, doi:10.1029/2005GL025318, 2006.

Hainbucher, D., Rubino, A., Cardin, V., Tanhua, T., Schroeder, K., and Bensi, M.: Hydrographic situation during cruise M84/3 and P414 (spring 2011) in the Mediterranean Sea, Ocean Sci., 10, 669-682, doi:10.5194/os-10-669-2014, 2014.
Hemleben, C., Roether, W., and Stoffers, P. (Eds.): Östliches Mittelmeer, Rotes Meer, Arabisches Meer, Cruise No. 31, 30 December 1994-22 March 1995, METEOR-Berichte, Universität Hamburg, 96-4, 282 pp., 1996.

Hemleben, C., Hoernle, K., Jørgensen, B.B., and Roether, W. (Eds.): Ostatlantik, Mittelmeer, Schwarzes Meer, Cruise No. 51, 12 September-28 December 2001, METEOR-Berichte, Universität Hamburg, 03-1, 225 pp., 2003.

Klein, B., Roether, W., Manca, B. B., Bregant, D., Beitzel, V., Kovačević, V., and Luchetta, A.: The large deep water transient in the Eastern Mediterranean, Deep-Sea Res. Pt. I, 46, 371-414, 1999.

Klein, B., Roether, W., Manca, B., and Theocharis, A.: The evolution of the Eastern Mediterranean Climatic transient during the last decade: the tracer viewpoint, in: The Eastern Mediterranean Transient, edited by: Briand, F., CIESM Workshop Series, vol. 10. CIESM, Monaco, 21-25, 2000.

Kondo, J.: Air-sea bulks transfer coefficients in adiabatic conditions, Bound-Lay. Meteorol., 9, 91-112, 1975.

Lascaratos, A., Roether, W., Nittis, K., and Klein, B.: Recent changes in deep water formation and spreading in the eartern Mediterranean Sea: a review, Prog. Oceanogr., 44, 5-36, 1999.

Maillard, C., Balopoulos, E., Giorgetti, A., Fichaut, M., Iona, S., Larour, M., Latrouite, A., Manca, B. B., Maudire, G., Nicolas, P., and Sanchez-Cabeza, J.-A.: An integrated system for managing multidisciplinary oceanographic data collected in the Mediterranean Sea during the basin-scale research project EU/MASTMATER (1996-2000), J. Marine Syst., 33-34, 523-538, 2002.

Malanotte-Rizzoli, P., Manca, B., Ribera D’Alcalà, M., Theocharis, A., Bergamasco, A., Bregant, D., Budillon, G., Civitarese, G., Georgopoulos, D., Michelato, A., Sansone, E., Scarazzato, P., and Souvermezoglou, E.: A synthesis of the Ionian Sea hydrography, circulation and water mass pathways during POEM Phase I, Progr. Oceanogr., 39, 153-204, 1997.

Malanotte-Rizzoli, P., Manca, B. B., Ribera d'Alcala, M., Theocharis, A., Brenner, S., Budillon, G., and Ozsoy, E.: The Eastern Mediterranean in the 80s and in the 90s: the big transition in the intermediate and deep circulations, Dynam. Atmos. Oceans, 29, 365-395, 1999.

Molcard, A., Pinardi, N., Iskandarani, M., and Haidvogel, D. B.: Wind driven general circulation of the Mediterranean Sea simulated with a Spectral Element Ocean Model, Dynam. Atmos. Oceans, 35, 97-130, 2002.

Manca, B. B., Budillon, G., Scarazzato, P., and Ursella, L.: Evolution of dynamics in the eastern Mediterranean affecting water mass structures and properties in the Ionian and Adriatic Seas, J. Geophys. Res., 108, 8102, doi:10.1029/2002JC001664, 2003.

Manca, B. B., Burca, M., Giorgetti, A., Coatanoan, C., García, M., and Iona, A.: Physical and biogeochemical averaged vertical profiles in the Mediterranean regions: an important tool to trace the climatology of water masses and to validate incoming data from operational oceanography, J. Marine Syst., 48, 83-116, 2004.

Manca, B. B., Ibello, V., Pacciaroni, M., Scarazzato, P., and Giorgetti, A.: Ventilation of deep waters in the Adriatic and Ionian Seas following changes in thermohaline circulation of the Eastern Mediterranean, Clim. Res., 31, 239-256, 2006.

Moutin, T., Van Wambeke, F., and Prieur, L.: Introduction to the Biogeochemistry from the Oligotrophic to the Ultraoligotrophic 
Mediterranean (BOUM) experiment, Biogeosciences, 9, 38173825, doi:10.5194/bg-9-3817-2012, 2012.

Nellen, W., Bettac, W., Roether, W., Schnack, D., Thiel, H., Weikert, H., and Zeitschel, B. (Eds.): MINDIK (Band II), Reise Nr. 5, 2 January-24 September 1987m METEOR-Berichte, Universität Hamburg, 96-2, 179 pp., 1996.

Pätzold, J., Halbach, P. E., Hempel, G., and Weikert, H. (Eds.): Östliches Mittelmeer - Nördliches Rotes Meer 1999, Cruise No. 44, 22 January-16 May 1999m METEOR-Berichte, Universität Hamburg, 00-3, 240 pp., 2000.

Pinardi, N., Zavatarelli, M., Adani, M., Coppini, G., Fratianni, C., Oddo, P., Simoncelli, S., Tonani, M., Lyubartsev, V., Dobricic, S., and Bonaduce, A.: Mediterranean Sea large-scale low-frequency ocean variability and water mass formation rates from 1987 to 2007: A retrospective analysis, Prog. Oceanogr., doi:10.1016/j.pocean.2013.11.003, in press, 2013.

Rio, M.-H., Poulain, P.-M., Pascal, A., Mauri, E., Larnicol, G., and Santoleri, R.: A mean dynamic topography of the Mediterranean Sea computed from altimetric data, in-situ measurements and a general circulation model, J. Marine Syst., 65, 484-508, 2007.

Robinson, A. R., Golnaraghi, M., Leslie, W. G., Artegiani. A., Hecht, A., Lazzoni, E., Michelato, A., Sansone. E., Theocharis, A., and Unluata, U.: The eastern Mediterranean general circulation: features, structures and variability, Dynam. Atmos. Oceans, 15, 215-240, 1991.

Roether, W. and Schlitzer, R.: Eastern Mediterranean deep water renewal on the basis of chlorofluoromethane and tritium data, Dynam. Atmos. Oceans, 15, 333-354, 1991.

Roether, W., Manca, B.B., Klein, B., Bregant, D., Georgopoulos, D., Beitzel, V., Kovačević, V., and Luchetta, A.: Recent changes in Eastern Mediterranean deep waters, Science, 271, 333-335, 1996.

Roether, W., Klein, B., Manca, B. B., Theocharis, A., and Kioroglou, S.: Transient Eastern Mediterranean deep waters in response to the massive dense-water output of the Aegean Sea in the 1990s, Prog. Oceanogr., 74, 540-571, 2007.

Roether, W., Klein, B., and Hainbucher, D.: The Eastern Mediterranean Transient: evidence for similar events previously?, in: AGU monographs: The Mediterranean Sea: Temporal Variability and Spatial Patterns, edited by: Borzelli, G. L. E., Gačić, M., Lionello, P., and Malanotte-Rizzoli, P., John Wiley \& Sons, Inc., 75-83, 2014.
Rubino, A. and Hainbucher, D.: A large abrupt change in the abyssal water masses of the eastern Mediterranean, Geophys. Res. Lett., 34, L23607, doi:10.1029/2007GL031737, 2007.

Schiano, E.: Insolation over the western Mediterranean Sea: A comparison of direct measurements and Reed's formula, J. Geophys. Res., 101, 3831-3838, 1996.

Schlitzer, R., Roether, W., Hausmann, M., Junghans, H.-G., Oster, H., Johannsen, H., and Michelato, A.: Chlorofluoromethane and oxygen in the Eastern Mediterranean, Deep-Sea Res. Pt. I, 38, 1531-1551, 1991.

Tanhua, T., Hainbucher, D., Cardin, V., Álvarez, M., Civitarese, G., McNichol, A. P., and Key, R. M.: Repeat hydrography in the Mediterranean Sea, data from the Meteor cruise 84/3 in 2011, Earth Syst. Sci. Data, 5, 289-294, doi:10.5194/essd-5-289-2013, 2013.

Theocharis, A., Nittis, K., Kontoyannis, H., Papageorgiou, E., and Balopoulos, E.: Climatic changes in the Aegean Sea influence the eastern Mediterranean thermohaline circulation (1986-1997), Geophys. Res. Lett., 26, 1617-1620, 1999.

Theocharis, A., Klein, B., Nittis, K., and Roether, W.: Evolution and status of the Eastern Mediterranean Transient (1986-1999), Geophys. Res. Lett., 26, 1617-1620, 2002.

Theocharis, A., Krokos, G., Velaoras, D., and Korres, G.: An internal mechanism driving the alternation of the Eastern Mediterranean dense/deep water sources, in AGU monographs: The Mediterranean Sea: Temporal Variability and Spatial Patterns, edited by: Borzelli, G. L. E., Gačić, M., Lionello, P., and Malanotte-Rizzoli, P., John Wiley \& Sons, Inc., 113-137, 2014.

Touratier, F. and Goyet, C.: Impact of the Eastern Mediterranean Transient on the distribution of anthropogenic $\mathrm{CO}_{2}$ and first estimate of acidification for the Mediterranean Sea, Deep-Sea Res. Pt. I, 58, 1-15, 2011.

Velaoras, D., Krokos, G., Nittis, K., and Theocharis A.: Dense intermediate water outflow from the Cretan Sea: A salinity driven, recurrent phenomenon, connected to thermohaline circulation changes, J. Geophys. Res.-Oceans, 119, 4797-4820, doi:10.1002/2014JC009937, 2014. 